\title{
Zedoarondiol Attenuates Endothelial Cells Injury Induced by Oxidized Low-Density Lipoprotein via Nrf2 Activation
}

\author{
Huimin Mao a,b,c Tianqi Tao ${ }^{c}$ Xiaoren Wang ${ }^{c}$ Mi Liub,c $^{\mathrm{b}, \mathrm{Dandan} S o n{ }^{\mathrm{c}}}$ \\ Xiuhua Liuc Dazhuo Shib \\ aDepartment of Nephrology, Guang'anmen Hospital, China Academy of Chinese Medical Sciences, \\ Beijing, ' Cardiovascular Disease Center, Xiyuan Hospital, China Academy of Chinese Medical Sciences, \\ Beijing, 'Department of Pathophysiology, Chinese PLA General Hospital, Beijing, China
}

\section{Key Words}

Zedoarondiol $\bullet$ Endothelial cells $\bullet \mathrm{Nrf2} \cdot$ Oxidative stress $\bullet$ Inflammation

\begin{abstract}
Background/Aims: Zedoarondiol, a sesquiterpene lactone compound, showed an antiproliferative activity on vascular smooth muscle cells in our previous study. However, whether it has a beneficial effect on endothelial cells injury induced by oxidized low-density lipoprotein (ox-LDL) remains unclear. This study was designed to investigate the protective effect of zedoarondiol on ox-LDL-induced injury of endothelial cells and explored its underlying mechanism. Methods: The protective effect of zedoarondiol on ox-LDL-induced human umbilical vein endothelial cells (HUVECs) injury were evaluated by Cell Counting Kit$8(C C K-8)$ assay and released lactic dehydrogenase (LDH) activity assay. Oxidative stress was determined by malonedialdehyde (MDA) content and superoxide dismutase (SOD) activity. The level of reactive oxygen species (ROS) was measured by dichlorodihydrofluorescin diacetate (DCFH-DA) staining. The culture supernatant was collected for enzyme linked immune-sorbent assays (ELISA) of interleukine-1 $\beta$ (IL-1 $\beta$ ), tumor necrosis factor- $\alpha$ (TNF- $\alpha$ ), and monocyte chemoattractant protein-1 (MCP-1). Immunofluorescence staining was used to observe NF-E2-related factor 2 (Nrf2) translocation. Western blotting was performed to determine the expression of IL-1 $\beta$, TNF- $\alpha$, MCP-1, Kelch-like ECH associated protein 1 (Keap1), heme oxygenase-1 (HO-1), NAD(P)H: quinone oxidoreductase-1 (NQO1), and Nrf2. Results: Zedoarondiol attenuated HUVECs injury, up-regulated SOD activity, suppressed formation of MDA and ROS, and secretion and protein expression of IL-1 $\beta$, TNF- $\alpha$, and MCP- 1 in injured HUVECs induced by ox-LDL. Zedoarondiol induced nuclear Nrf2 translocation from cytoplasm into nucleus and up-regulated expression of $\mathrm{HO}-1, \mathrm{NQO} 1$, and Nrf2 in nucleus. All-trans-retinoic acid (ATRA), an inhibitor of Nrf2, abolished zedoarondiol-mediated anti-
\end{abstract}




\section{Cellular Physiology Cell Physiol Biochem 2018;48:1468-1479 \\ \begin{tabular}{l|l} 
DOI: 10.1159/000492257 & O 2018 The Author(s). Published by S. Karger AG, Basel \\
www.karger.com/cpb
\end{tabular} \\ Mao et al.: Zedoarondiol Attenuates Endothelial Cells Injury via Nrf2}

oxidative effect. Conclusion: Zedoarondiol attenuates ox-LDL-induced endothelial cells injury by inhibiting oxidative stress and inflammation via Nrf2/HO-1 pathway, suggesting that zedoarondiol might be meaningful on prevention and treatment of atherosclerosis.

(C) 2018 The Author(s)

Published by S. Karger AG, Basel

\section{Introduction}

Endothelial cell dysfunction plays a vital role in the initiation and development of atherosclerosis (AS) [1], which can be induced by various risk factors, such as oxidized lowdensity lipoprotein (ox-LDL), hyperglycemia, and hypertension [2]. Ox-LDL is considered as a vital contributor to endothelial cell dysfunction [3]. Therefore, attenuating ox-LDL-induced endothelial cell injury is a promising strategy against AS.

Zedoarondiol (Fig. 1A), a sesquiterpene lactone, is an active compound extracted from Zedoariae rhizoma (Curcuma zedaria Roscoe). It has been reported that zedoarondiol attenuated D-galactosamine-induced liver injury in mice $[4,5]$ and inhibited inflammation in lipopolysaccharide (LPS)-stimulated murine macrophages via suppressing nuclear factor-kappa B (NF- $\kappa$ B) pathway [6]. Our previous study has demonstrated that coating stents with Zedoariae rhizoma essential components, mainly including zedoarondiol, suppressed neointimal formation and showed a well-developed endothelium in a porcine coronary arterial balloon-injury model [7], suggesting that essential components of Zedoariae rhizoma play a favorable role in regulating vascular smooth muscle cells (VSMCs) proliferation and protecting injured endothelial cells. Moreover, our previous study also showed that zedoarondiol inhibited platelet-derived growth factor-BB (PDGF-BB)-induced VSMCs proliferation via AMP-activated protein kinase pathway [8]. However, little is known about the role of zedoarondiol in protecting injured endothelial cells.

In response to ox-LDL stimulation, endothelial cells undergo a series of biological changes, involving reducing nitric oxide bioavailability, triggering oxidative stress, and initiating inflammation, collectively accelerating atherogenesis [9-11]. Nuclear factorerythroid 2-related factor 2 (Nrf2), a redox-sensitive transcription factor, plays an important role in regulating cellular oxidative stress and inflammation. In physiological conditions, Nrf2 locates in the cytoplasm adjacent to Kelch-like ECH-associated protein 1 (Keap1) that suppresses Nrf2 activity. In the presence of oxidative or electrophilic stress, Nrf2 is released from Keap1, translocates to the nucleus, which results in binding to antioxidant response elements (ARE) in the promoter region and subsequently promoting the transcription of antioxidant and detoxifying genes, including heme oxygenase-1 (HO-1), NAD(P)H: quinone oxidoreductase-1 (NQ01), glutathione-S-transferases (GSTs), glutathione peroxidase (GPx), and so forth [12]. Nrf2 activation protects endothelial cells from oxidative damage [13] and inflammatory reaction [14], indicating Nrf2 as a novel therapeutic target for AS [15, 16].

In the present study, we hypothesized that zedoarondiol attenuates endothelial cells injury induced by ox-LDL by inhibiting oxidative stress and inflammation via Nrf2 activation. To test this hypothesis, we investigated the effect of zedoarondiol on ox-LDL-induced human umbilical vein endothelial cells (HUVECs) injury and explored its underlying mechanisms focusing on Nrf2 pathway.

\section{Materials and Methods}

\section{Materials}

Zedoarondiol was kindly provided by the Dalian Institute of Chemical Physics, Chinese Academy of Sciences (Dalian, Liaoning, China). Ox-LDL (UBC-ox-LDL5) was purchased from Beijing Peking UnionBiology Co. Ltd (Beijing, China). According to manufacturer's instruction, ox-LDL was fully oxidized and its

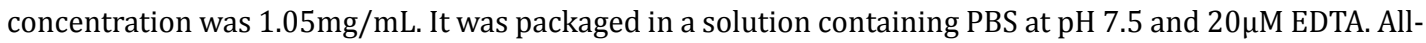
trans-retinoic acid (ATRA) was purchased from Sigma-Aldrich (St. Louis, MO, USA). Zedoarondiol and ATRA were dissolved in dimethylsulfoxide (DMSO, final concentration < 0.1\%). The Cell Counting Kit-8 (CCK-8) was 


\section{Cellular Physiology Cell Physiol Biochem 2018;48:1468-1479 \\ and Biochemistry Publisned onIIne: July 31, $2018 \quad \begin{aligned} & \text { DOI: 10.1159/000492257 } 2018 \text { The Author(s). Published by S. Karger AG, Basel } \\ & \text { www.karger.com/cpb }\end{aligned}$}

Mao et al.: Zedoarondiol Attenuates Endothelial Cells Injury via Nrf2

purchased from Dojindo Laboratories (Kumamoto, Japan). Endothelial Cell Medium (ECM) was purchased from Sciencell (San Diego, CA, USA). Assay kits of lactate dehydrogenase (LDH), malonedialdehyde (MDA), superoxide dismutase (SOD) and reactive oxygen species (ROS) were obtained from Jiancheng Biotech (Nanjing, Jiangsu, China). ELISA kits for interleukine-1 $\beta$ (IL-1 $\beta$ ), tumor necrosis factor- $\alpha$ (TNF- $\alpha$ ), and monocyte chemoattractant protein-1 (MCP-1) were purchased from Jiancheng Biotech (Nanjing, Jiangsu, China). The enhanced chemiluminescence (ECL) kit was obtained from Santa Cruz Biotechnology (Santa Cruz, CA, USA). Antibodies against IL-1 $\beta$ (sc-7884), TNF- $\alpha$ (sc-52746), MCP-1 (sc-52877), Nrf2 (sc-722), histone H3 (sc-8654), and $\beta$-actin (sc-81178) were purchased from Santa Cruz Biotechnology (Santa Cruz, CA, USA). Antibodies against Keap1 (8047) and NQ01 (3187) were purchased from Cell Signaling Technology (Danvers, MA, USA). The antibody for HO-1 (ab13248) and LOX-1 (ab60178) were purchased from Abcam (Cambridge, MA, USA). Horseradish peroxidase (HRP)-conjugated goat anti-rabbit immunoglobulin G (IgG) and anti-mouse IgG were obtained from Epitomics (Burlingame, CA, USA). NE-PER Nuclear and Cytoplasmic Extraction kit was purchased from Thermo Fisher Scientific (Waltham, MA, USA). The mounting medium with DAPI was obtained from Vector Laboratories (Burlingame, CA, USA).

\section{Cell culture and treatment}

HUVECs were purchased from ScienCell (San Diego, CA, USA). Cells were cultured in ECM with 5\% fetal bovine serum (FBS), 1\% endothelial cell growth supplement (ECGS), and 1\% penicillin/streptomycin solution in a humidified atmosphere with $5 \% \mathrm{CO}_{2}$ at $37^{\circ} \mathrm{C}$. HUVECs at passage 4-6 were used in the experiments. Each experiment was performed on HUVECs from three different donors.

To exclude the possibility that the solvent of ox-LDL, zedoarondiol and ATRA affect the experimental results, the solvent controls were designed in the preliminary experiment. The results showed that the treatment with EDTA $(2.9 \mu \mathrm{M}$, the solvent of ox-LDL), DMSO $(0.1 \%$, the solvent of zedoarondiol and ATRA) or EDTA $(2.9 \mu \mathrm{M})+$ DMSO $(0.1 \%)$ had no significant impact on HUVECs viability and MDA concentration as compared with the control (Fig. 1B-C).

To evaluate the effect of zedoarondiol on ox-LDL-induced HUVECs injury, cells were designed to the following groups: (1) control group: HUVECs were cultured routinely for $24 \mathrm{~h}$; (2) ox-LDL group: HUVECs were treated with ox-LDL (150 $\mu \mathrm{g} / \mathrm{mL})$ [17] for $24 \mathrm{~h}$; (3) three zedoarondiol pretreatment groups: HUVECs were pretreated with zedoarondiol at 5,10 , or $20 \mu \mathrm{g} / \mathrm{mL}$ [8] for $2 \mathrm{~h}$, respectively, and then treated with ox-LDL (150 $\mu \mathrm{g} / \mathrm{mL})$ for $24 \mathrm{~h}$; (4) Zed group: HUVECs were treated with zedoarondiol $(20 \mu \mathrm{g} / \mathrm{mL})$ for $24 \mathrm{~h}$.

To determine the role of Nrf2 in zedoarondiol-mediated protective effect on ox-LDL-induced HUVECs injury, cells were divided into the five groups: (1) control group; (2) Zed group; (3) ox-LDL group; (4) oxLDL+Zed group: HUVECs were pretreated with zedoarondiol $(20 \mu \mathrm{g} / \mathrm{mL})$ for $2 \mathrm{~h}$ and then treated with ox-LDL (150 $\mu \mathrm{g} / \mathrm{mL})$ for $24 \mathrm{~h}$; (5) ox-LDL+Zed+ATRA group: HUVECs were pretreated with zedoarondiol $(20 \mu \mathrm{g} / \mathrm{mL})$ and ATRA (5 $\mu \mathrm{mol} / \mathrm{L})$ [18] for $2 \mathrm{~h}$ and then treated with ox-LDL $(150 \mu \mathrm{g} / \mathrm{mL})$ for $24 \mathrm{~h}$. The treatment of the first three groups was same to the above.

\section{Cell viability}

Cell viability was evaluated using the CCK-8 assay kit. HUVECs were plated in 96-well plates at a density of $5 \times 10^{3}$ cells/well. After treatment, $10 \mu \mathrm{L}$ CCK-8 was added to each well for $2 \mathrm{~h}$ at $37^{\circ} \mathrm{C}$. Absorbance at $450 \mathrm{~nm}$ was measured using a microplate reader (Tecan Infinite f200 Pro, Tecan Group Ltd, Männedorf, Switzerland).

\section{LDH activity}

HUVECs were plated in 6-well plates at a density of $2 \times 10^{5}$ cells/well. LDH in the culture medium was evaluated using a LDH activity assay kit (Jiancheng Biotech, Nanjing, Jiangsu, China) according to the manufacturer's protocol. Briefly, the medium samples were incubated with NADH and pyruvate for 15 min at $37^{\circ} \mathrm{C}$. The enzymatic reaction was stopped by adding $0.4 \mathrm{~mol} / \mathrm{L} \mathrm{NaOH}$. Absorbance at $450 \mathrm{~nm}$ was measured by the microplate reader.

\section{MDA level and SOD activity}

Cells were seeded in T-25 flasks at a density of $5 \times 10^{5}$ cells/flask. After treatment, cells were collected and resuspended in lysis buffer. Protein concentration was determined using the bicin-choninic acid (BCA) method. The MDA level was measured by the thiobarbituric acid (TBA) method using a lipid peroxidation 


\section{Cellular Physiology Cell Physiol Biochem 2018;48:1468-1479 \begin{tabular}{l|l} 
DOI: 10.1159/000492257 & $\begin{array}{l}\text { O 2018 The Author(s). Published by S. Karger AG, Basel } \\
\text { www.karger.com/cpb }\end{array}$
\end{tabular}}

Mao et al.: Zedoarondiol Attenuates Endothelial Cells Injury via Nrf2

MDA assay kit (Jiancheng Biotech, Nanjing, Jiangsu, China) according to the manufacturer's instructions. Absorbance at $530 \mathrm{~nm}$ was measured by the microplate reader. SOD activity was evaluated by the xanthine oxidase method using a SOD activity assay kit (Jiancheng Biotech, Nanjing, Jiangsu, China) according to the manufacturer's instructions. Absorbance was measured at $450 \mathrm{~nm}$ by the microplate reader.

\section{ROS production}

ROS production was determined using a ROS assay kit (Beyotime Biotech, Shanghai, China) according to the manufacturer's protocol. Cells were seeded in 6 -well plates at a density of $2 \times 10^{5}$ cells/well. After treatment, cells were harvested, washed twice with PBS, and incubated with serum-free media containing $10 \mu \mathrm{mol} / \mathrm{L}$ DCFH-DA at $37^{\circ} \mathrm{C}$ for $30 \mathrm{~min}$ in the dark. Subsequently, cells were washed twice with serum-free medium. The ROS level was detected using a FACSCalibur flow cytometer (BD Biosciences, Franklin Lakes, NJ, USA).

\section{Levels of $I L-1 \beta, T N F-\alpha$, and $M C P-1$}

The levels of IL-1 $1 \beta$, TNF- $\alpha$, and MCP-1 in the culture medium were determined by ELISA (Jiancheng Biotech, Nanjing, Jiangsu, China) according to the manufacturer's instructions. Briefly, $50 \mu \mathrm{L}$ standard solution or culture medium was added to each well, followed by incubation with a HRP-conjugated secondary antibody (50 $\mu \mathrm{L} /$ well) for $2 \mathrm{~h}$ at $37{ }^{\circ} \mathrm{C}$. Cells were washed three times with washing buffer and incubated with $100 \mu \mathrm{L} /$ well substrate solution for $10 \mathrm{~min}$ at $37{ }^{\circ} \mathrm{C}$. $50 \mu \mathrm{L}$ of sulfuric acid (1 M) was added to stop the enzymatic reaction and the absorbance was measured at $450 \mathrm{~nm}$ by the microplate reader.

\section{Nrf2 nuclear translocation}

Nrf2 nuclear translocation was observed by immunofluorescence staining. HUVECs grown on coverslips were fixed in $4 \%$ paraformaldehyde for $15 \mathrm{~min}$ at $4{ }^{\circ} \mathrm{C}$ and blocked with $10 \%$ donkey serum containing 1 $\%$ BSA and $0.2 \%$ Triton X-100 for 50 min at room temperature. Next, cells were incubated with anti-Nrf2 rabbit polyclonal antibody (1:50 diluted) overnight at $4{ }^{\circ} \mathrm{C}$ and then probed with Texas red-conjugated donkey anti-rabbit secondary antibody $(1: 100)$ for $2 \mathrm{~h}$ at room temperature in the dark. DAPI was added for nuclear staining. The cells were observed under a confocal scanning microscope $(630 \times$ amplification; Zeiss LSM-510 Meta, Jena, Germany). For the quantitative analysis, mean fluorescence intensity per cell was calculated from 3 random fields of each group with Image-Pro Plus software (Roper Industries, New York, NY, USA).

\section{Western blot analysis}

Cells were collected and lysed in lysis buffer containing HEPES $(20.0 \mathrm{mM}), \beta$-glycerophosphate (20 mM), Na3VO4 (0.1 mM), MgCl2 (2.5 mM), NaCl (5 mM), DTT (0.5 mM), EDTA (0.1 mM), leupeptin 4 $(\mu \mathrm{g} / \mathrm{mL})$, PMSF $20(\mu \mathrm{g} / \mathrm{mL})$, and Triton X-100 $(0.05 \% \mathrm{v} / \mathrm{v})$. The protein concentration was measured by BCA method. The equivalent amounts of protein $(80 \mu \mathrm{g} / \mathrm{lane})$ was separated by $8-12 \%$ sodium dodecyl sulfate-polyacrylamide gels for electrophoresis and then electrophoretically transferred to nitrocellulose membranes. After blocked with $5 \%$ bovine serum albumin (BSA) in Tris-buffered saline containing $0.1 \%$ Tween 20 (TBS-T) for $2 \mathrm{~h}$ at room temperature, the membranes were incubated with primary antibodies at $4{ }^{\circ} \mathrm{C}$ overnight. The membranes were incubated with corresponding HRP-conjugated secondary antibodies for $2 \mathrm{~h}$. Protein bands were visualized using an ECL kit. Image-Pro Plus software was applied to quantify the optical density of bands. Protein expression was normalized to $\beta$-actin. In addition, Nrf2 protein in the cytoplasm and nucleus were obtained by using NE-PER nuclear and cytoplasmic extraction reagents. Histone $\mathrm{H} 3$ was used as an internal control for nuclear Nrf2 protein.

\section{Statistical analyses}

SPSS 17.0 software (IBM, Chicago, IL, USA) was applied for statistical analyses. Data were presented as mean \pm standard deviation (SD). Differences were evaluated by one-way analysis of variance (ANOVA) followed by Tukey's post-hoc test. A value of $P<0.05$ was considered statistically significant. 


\section{Cellular Physiology Cell Physiol Biochem 2018;48:1468-1479 and Biochemistry \begin{tabular}{l|l} 
DOI: 10.1159/000492257 & $\begin{array}{l}\text { (c) } 2018 \text { The Author(s). Published by S. Karger AG, Basel } \\
\text { www.karger.com/cpb }\end{array}$
\end{tabular} \\ Mao et al.: Zedoarondiol Attenuates Endothelial Cells Injury via Nrf2}

\section{Results}

Zedoarondiol increases viability and inhibits released $L D H$ activity in injured HUVECS induced by ox- $L D L$

In the present study, we first evaluated the protective effect of zedoarondiol on ox-LDL-induced HUVECs injury by CCK-8 assay. Ox-LDL $(150 \mu \mathrm{g} / \mathrm{mL})$ significantly decreased HUVECs viability by $58 \%$ $(P<0.05$ vs. control). As compared with the ox-LDL group, zedoarondiol pretreatment at 5,10 , and $20 \mu \mathrm{g} / \mathrm{mL}$

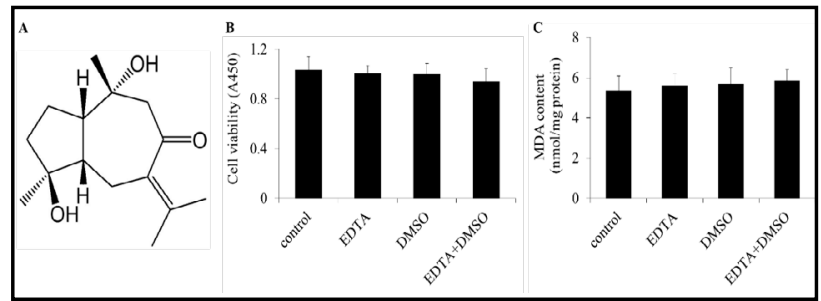

Fig. 1. Chemical structure of zedoarondiol (A) and the effect of solvent on cell viability and MDA concentration. HUVECs were incubated with EDTA $(2.9 \mu \mathrm{M})$, DMSO $(0.1 \%)$, and EDTA $(2.9 \mu \mathrm{M})+$ DMSO $(0.1 \%)$ for $24 \mathrm{~h}$. (B) Cell viability. (C) MDA concentration. All data were expressed as mean \pm SD. $n=6$. followed by ox-LDL $(150 \mu \mathrm{g} / \mathrm{mL})$ treatment alleviated the decreased viability by $77 \%, 102 \%$, and $134 \%$, respectively $(P<0.05$ vs. ox-LDL; Fig. 2A). However, zedoarondiol $(20 \mu \mathrm{g} / \mathrm{mL})$ treatment did not affect the viability of HUVECs in the control group ( $P>0.05$ vs. control; Fig. $2 \mathrm{~A}$ ).

We examined the effect of zedoarondiol on ox-LDL-induced HUVECs injury by the released LDH activity assay. Ox-LDL $(150 \mu \mathrm{g} / \mathrm{mL})$ led to an increase in released LDH activity by $67 \%(P<0.05$ vs. control); pretreatment with zedoarondiol at 5,10 , and $20 \mu \mathrm{g} / \mathrm{mL}$ followed by ox-LDL $(150 \mu \mathrm{g} / \mathrm{mL})$ treatment attenuated LDH activity by $34 \%, 35 \%$, and $38 \%$, respectively $(P<0.05$ vs. ox-LDL; Fig. $2 \mathrm{~B})$. No significant difference was observed between the control group and Zed group $(P>0.05$; Fig. $2 \mathrm{~B})$.

\section{Zedoarondiol reduces ox-LDL-induced oxidative stress in HUVECs}

MDA is formed during lipid peroxidation caused by free radicals. SOD is a major endogenous antioxidant enzyme which protects endothelial cells against oxidative damage. Thus, we evaluated the effect of zedoarondiol on MDA level and SOD activity in injured HUVECs induced by ox-LDL. Ox-LDL markedly increased MDA level $(P<0.05$ vs. control) and decreased SOD activity $(P<0.05$ vs. control). When compared with ox-LDL group, pretreatment with zedoarondiol at 5, 10, and $20 \mu \mathrm{g} / \mathrm{mL}$ decreased MDA level by $21 \%, 31 \%$, and 37\%, respectively $(P<0.05$; Fig. $2 \mathrm{C})$; zedoarondiol pretreatment at 10 and $20 \mu \mathrm{g} / \mathrm{mL}$ alleviated the decreased SOD activity by $36 \%$ and $49 \%$, respectively $(P<0.05$ vs. ox-LDL; Fig. 2D). Zedoarondiol $(20 \mu \mathrm{g} / \mathrm{mL})$ treatment did not affect the MDA level and SOD activity of HUVECs in the control group ( $P>0.05$ vs. control).

Taken together, zedoarondiol at $20 \mu \mathrm{g} / \mathrm{mL}$ showed a pronounced protective effect on ox-LDL-induced HUEVCs injury. Therefore, zedoarondiol at $20 \mu \mathrm{g} / \mathrm{mL}$ was used in the subsequent experiments.

LOX-1, known as the major scavenger receptor for ox-LDL uptake in endothelial cells, plays a pivotal role in atherogenic process [19]. Thus, we first evaluated the effect of zedoarondiol on LOX-1 expression. Ox-LDL $(150 \mu \mathrm{g} / \mathrm{mL})$ led to a $124 \%$ increase in LOX-1 expression $(P<0.05$ vs. control). Zedoarondiol $(20 \mu \mathrm{g} / \mathrm{mL})$ pretreatment followed by ox-LDL down-regulated LOX-1 expression by $53 \%$ ( $P<0.05$ vs. ox-LDL; Fig. 2 E).

Increased ROS are a major cause of oxidative stress. We investigated the effect of zedoarondiol on intracellular ROS level by flow cytometry. As compared with the control group, ox-LDL treatment resulted in a 3.4-fold increase in ROS level $(P<0.05$ vs. control); pretreatment with zedoarondiol at $20 \mu \mathrm{g} / \mathrm{mL}$ decreased ROS level by $57 \%(P<0.05$ vs. oxLDL; Fig. 2F), indicating that the protective effect of zedoarondiol on ox-LDL-induced HUEVCs injury may be associated with reduced oxidative stress. 
Zedoarondiol attenuates ox $-L D L-i$ in $u$ c ed inflammation in HUVECs

To investigate the effect of zedoarondiol on inflammatory reaction in injured HUVECs induced by ox-LDL, levels of IL-1 $\beta$, MCP1 , and TNF- $\alpha$ in the culture medium were determined by ELISA. As compared with the control group, the levels of IL-1 $\beta$, MCP-1, and TNF- $\alpha$ were significantly increased in the ox-LDL group $(P<0.05)$; zedoarondiol $(20 \mu \mathrm{g} / \mathrm{mL})$ pretreatment followed by oxLDL $(150 \mu \mathrm{g} / \mathrm{mL})$ treatment reduced levels of IL-1 $\beta$, MCP- 1 , and TNF- $\alpha$ by $56 \%$, $67 \%$, and $42 \%$, respectively $(P<0.05$ vs. ox-LDL; Fig. 3A$C)$. There was no significant difference between the control group and Zed group $(P>0.05$ vs. control).

To further evaluate the inhibitory effect of zedoarondiol in ox-LDLinduced inflammation, the protein expression of IL$1 \beta$, MCP- 1 , and TNF- $\alpha$ were detected with western blotting. Ox-LDL treatment obviously increased protein expression of IL-1 $\beta$, MCP1 , and TNF- $\alpha \quad(P<0.05$ vs. control). In comparison with ox-LDL group, pretreatment with zedoarondiol $(20 \mu \mathrm{g} /$ $\mathrm{mL}$ ) led to a $14 \%, 51 \%$, and $26 \%$ reduction in protein expression of IL-1 $\beta$, MCP1 , and TNF- $\alpha$, respectively $(P<0.05$ vs. ox-LDL; Fig. $3 D-G)$, indicating that the cytoprotection effect of zedoarondiol was partly mediated by its anti-inflammatory activity.

Nrf2 activation is associated with protective effect of zedoarondiol-mediated on ox-LDLinduced HUVECs injury

To determine whether the protective effect of zedoarondiol on ox-LDL-induced HUVECs injury was mediated by Nrf2 activation, cells were co-treated with ATRA, an Nrf2 inhibitor. As compared with ox-LDL+Zed group, pretreatment with zedoarondiol and ATRA resulted in a 36\% increase in MDA level and a $14 \%$ decrease in SOD activity $(P<0.05$; Fig. 4A-B),
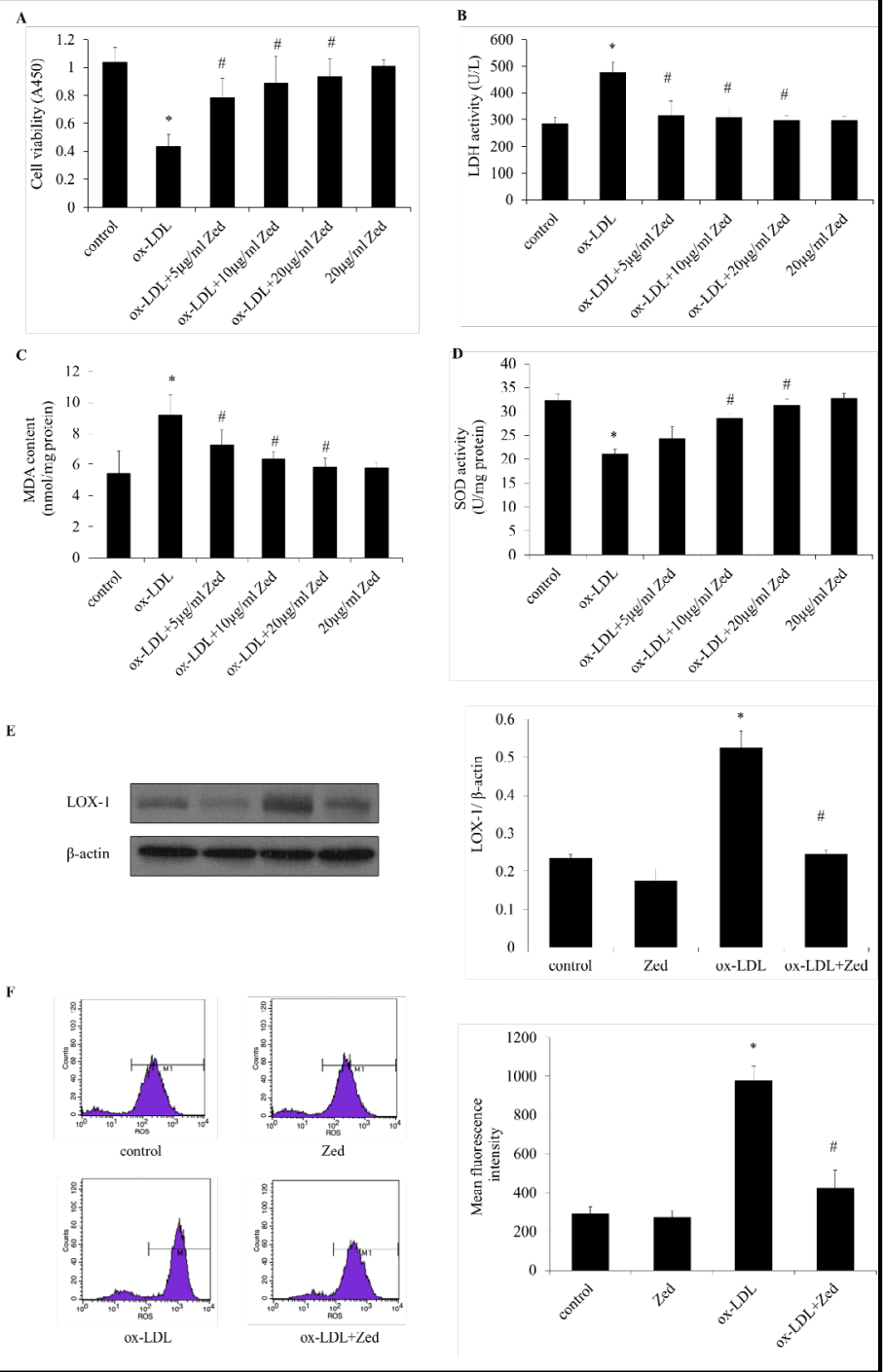

Fig. 2. Effect of zedoarondiol (Zed) on ox-LDL-induced HUVECs injury and oxidative stress. HUVECs were pre-incubated with zedoarondiol at 5 , or 10 , or $20 \mu \mathrm{g} / \mathrm{mL}$ for $2 \mathrm{~h}$, followed by ox-LDL $(150 \mu \mathrm{g} / \mathrm{mL})$ for 24 h. (A) Cell viability was evaluated by the CCK-8 assay. $n=6$. (B) Released LDH activity in the culture medium was evaluated by a LDH activity assay kit. $n=6$. Cells were collected for assays of (C) MDA level and (D) SOD activity. $n=3$. (E) Effect of zedoarondiol on LOX-1 expression. $n=3$. (F) HUVECs were probed with DCFH-DA and then subjected to the flow cytometry. $n=3$. All data were expressed as mean \pm SD. ${ }^{*} \mathrm{P}<0.05$ vs. control; ${ }^{*} \mathrm{P}<0.05$ vs. ox-LDL.

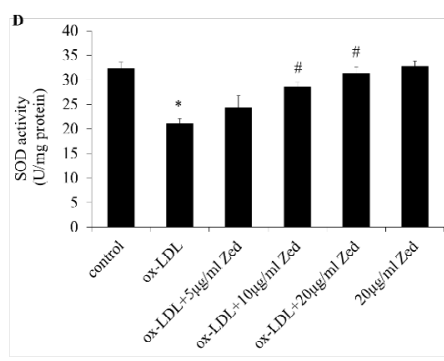




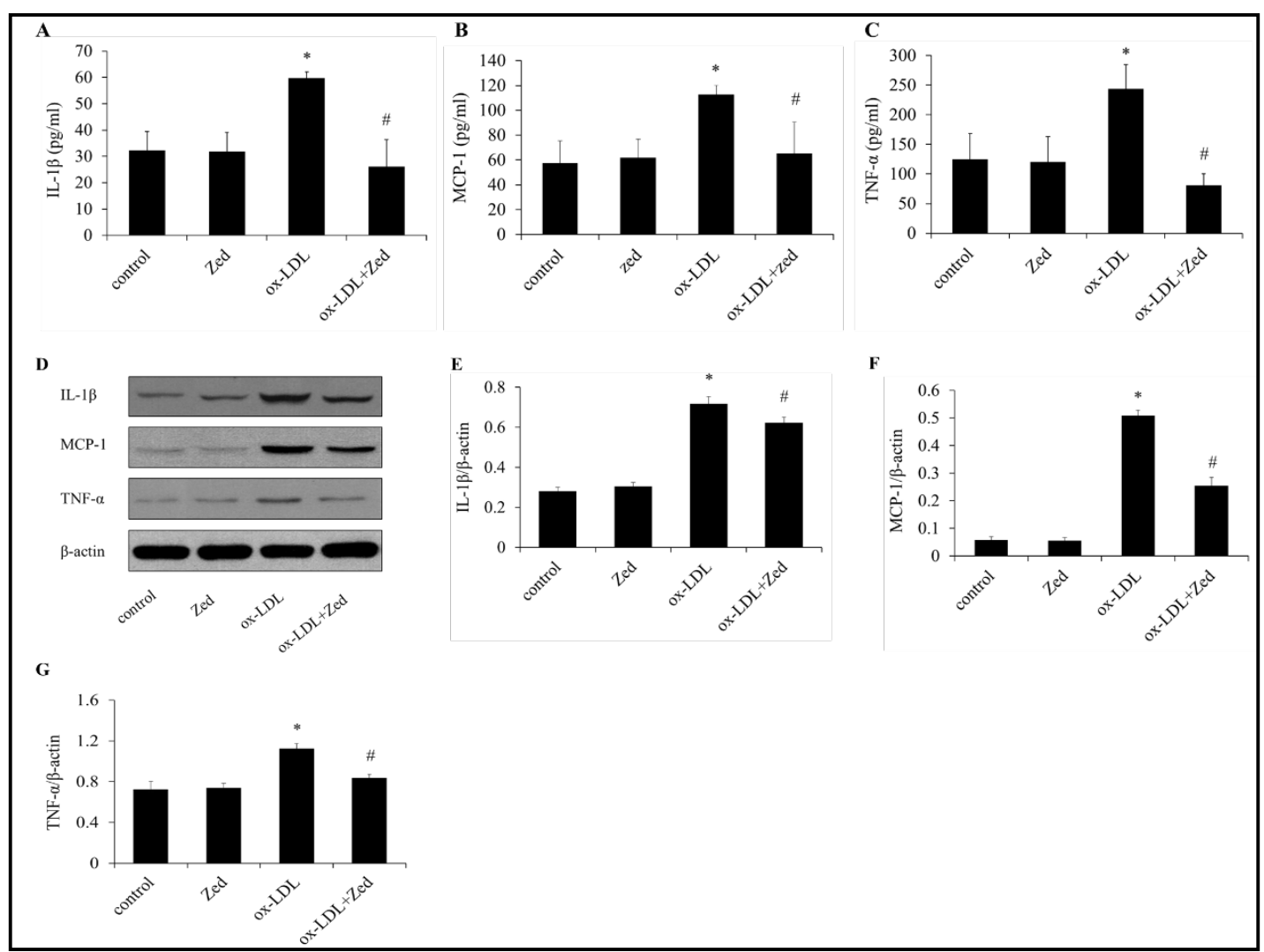

Fig. 3. Effect of zedoarondiol (Zed) on levels of IL-1 $\beta$, MCP-1, and TNF- $\alpha$ in ox-LDL-treated HUVECs. (A-C) The culture medium was collected and the levels of IL-1 $\beta$, MCP-1, and TNF- $\alpha$ were determined by ELISA. $\mathrm{n}=6$. (D-G) Cell lysates were analyzed by western blotting with primary antibodies against IL-1 $\beta$, MCP-1, and TNF- $\alpha$. Data were expressed as mean \pm SD. $n=3$. ${ }^{*} \mathrm{P}<0.05$ vs. control; ${ }^{\#} \mathrm{P}<0.05$ vs. ox-LDL.

Fig. 4. Effect of zedoarondiol (Zed) on Nrf2 pathway in ox-LDL-treated HUVECs. HUVECs were pre-incubated with/without Zed $(20 \mu \mathrm{g} / \mathrm{mL})$ or Zed+ATRA ( $5 \mu \mathrm{mol} / \mathrm{L}$ ) for $2 \mathrm{~h}$, and then stimulated with ox-LDL $(150 \mu \mathrm{g} / \mathrm{mL})$ for $24 \mathrm{~h}$. Cells were collected for assays of (A) MDA level and (B) SOD activity. $n=3$. (C) Nrf2 distribution was observed by immunofluorescence staining under a laser scanning confocal microscopy $(630 \times$, bar $=10 \mu \mathrm{m})$. For the quantitative analysis, mean fluorescence intensity per cell nucleus was calculated from 3 random fields of each group. $n=3$. Data were expressed as mean \pm SD. ${ }^{*} \mathrm{P}<0.05$ vs. control; ${ }^{\#} \mathrm{P}<0.05$ vs. ox-LDL; ${ }^{\circledR} \mathrm{P}<0.05$ vs. ox-LDL+Zed.

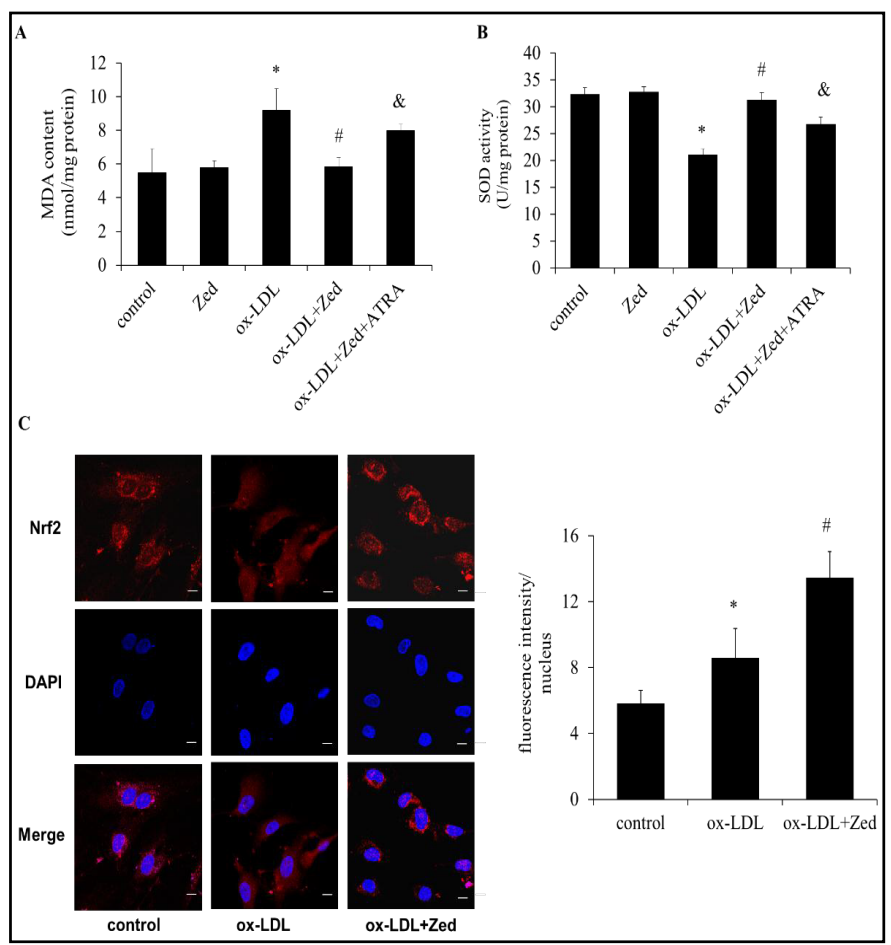


indicating that ATRA could reverse zedoarondiol-mediated anti-oxidative effect on injured HUVECs induced by ox-LDL.

Activated Nrf2 translocates into the nucleus and subsequently regulates the downstream target genes, such as HO-1, NQO1, GSTs, and GPx. Therefore, we observed Nrf2 nuclear translocation by immunofluorescence. Nrf2 distributed predominantly in the cytoplasm in the control group. As compared with ox-LDL group, the mean fluorescence intensity of nuclear Nrf2 in ox-LDL+Zed group was increased by $57 \%$ $(P<0.05$; Fig. 4C), suggesting that zedoarondiol induced Nrf2 nuclear translocation in the background of ox-LDL treatment.

To illustrate the role of Nrf2 in zedoarondiol-mediated protective effect on injured HUVECs induced by ox-LDL, Nrf2 protein expression in the cytoplasm and nucleus was detected with western blotting. As compared with ox-LDL group, zedoarondiol $(20 \mu \mathrm{g} /$ $\mathrm{mL}$ ) pretreatment followed by ox-LDL $(150 \mu \mathrm{g} / \mathrm{mL})$ resulted in a $19 \%$ decrease $(P<0.05$ vs. ox-LDL; Fig. 5A) in cytoplasmic Nrf2 protein and a $39 \%$ increase $(P<0.05$ vs. ox-LDL; Fig. 5B) in nuclear Nrf2. In addition, considering the vital role of Keap1 in Nrf2 translocation, Keap1 expression was detected. As compared with ox-LDL group, zedoarondiol pretreatment significantly inhibited Keap1 expression $(P<0.05$ vs. ox-LDL; Fig. $5 \mathrm{C}$ ), indicating that zedoarondiol induced Nrf2 translocation probably through suppressing Keap1 expression.

HO-1 and NQO1 are the crucial downstream of Nrf2, which are involved in Nrf2-mediated protective effect on injured endothelial cells $[20,21]$. Therefore, we detected expression of HO-1 and NQO1 with western blotting. In comparison with the control group, ox-LDL treatment increased HO-1 and NQO1 expression by $275 \%$ and $98 \%$, respectively $(P<0.05)$. Pretreatment with zedoarondiol further increased expression of HO-1 and NQO1 by $12 \%$ and $28 \%$, respectively, as compared with ox-LDL treatment alone $(P<0.05 ;$ Fig. 5D-E). 


\section{Cellular Physiology Cell Physiol Biochem 2018;48:1468-1479 \\ and Biochemistry Published onIIne: July 31, $2018 \quad \begin{aligned} & \text { DOI: 10.1159/000492257 } 2018 \text { The Author(s). Published by S. Karger AG, Basel } \\ & \text { www.karger.com/cpb }\end{aligned}$ \\ Mao et al.: Zedoarondiol Attenuates Endothelial Cells Injury via Nrf2}

\section{Discussion}

In this study, we investigated the effect of zedoarondiol on ox-LDL-induced HUVECs injury and explored its possible mechanism. Our findings demonstrated that: (1) zedoarondiol attenuated ox-LDL-induced endothelial cells injury, while it has no impact on the routine cultured endothelial cells; (2) the protective effect of zedoarondiol was associated with inhibition of oxidative stress and inflammation via Nrf2 pathway.

Endothelial cells dysfunction is well-known as a critical event in the AS pathogenesis [22]. Given the critical role of ox-LDL in endothelial cell dysfunction and subsequent AS [23], we used the model of ox-LDL-induced HUVECs injury to investigate the protective effect of zedoarondiol. Zedoarondiol is a sesquiterpene lactone extracted from Zedoariae rhizome. The present study demonstrated that zedoarondiol alleviated ox-LDL-induced HUVECs injury, as evidenced by alleviated decreased cell viability and inhibited released LDH activity in the culture medium. Our previous study showed that zedoarondiol inhibited PDGF-BBinduced VSMCs proliferation via AMP-activated protein kinase pathway [8]. Because that end othelial cells, macrophages and VSMCs collectively modulate the development of AS [24], zedoarondiol is supposed to be meaningful on prevention and treatment of AS.

Oxidative stress is closely associated with endothelial cell injury and AS pathogenesis [25]. Oxidative stress induced by ox-LDL mainly results from excessive ROS generation and decreased activity of anti-oxidative enzymes, such as SOD [26]. This study revealed that oxLDL elevated the level of MDA, a lipid peroxidation marker, increased ROS generation, and decreased SOD activity. Zedoarondiol pretreatment markedly attenuated ox-LDL-induced oxidative stress, as evidenced by increased SOD activity and decreased levels of MDA and ROS, indicating that zedoarondiol-mediated protective effect on ox-LDL-induced HUVECs injury is related to inhibiting oxidative stress. Notably, in the present study, the level of intracellular ROS was determined by a flow cytometer using DCFH-DA fluorescent probe, which has been recognized as a classic method to determine ROS generation. However, DCFH-DA is not ROSspecific, which can be also oxidized by nitric oxide and other low-molecular weight oxidants. Therefore, the ROS level may be underestimated.

Inflammation participates in AS formation from onset of AS plaque to plaque rupture $[27,28]$. Inflammatory cytokines, such as IL- $1 \beta$ and TNF- $\alpha$, up-regulate endothelial adhesion molecules and promote the recruitment of monocytes into the sub-endothelium [29]. MCP1 , a potent monocyte attractant, also contributes to monocyte recruitment [30]. Recently, anti-inflammatory therapies have been proposed as possible adjuncts to the current treatment for AS [31]. Zedoarondiol has been reported to have an anti-inflammatory effect on LPS-stimulated murine macrophage [6]. The finding in the present study showed that zedoarondiol significantly decreased both secretion and protein expression of IL-1 $\beta$, TNF- $\alpha$, and MCP-1 in injured HUVECs induced by ox-LDL, indicating that zedoarondiol attenuates ox-LDL-induced inflammation in HUVECs.

Nrf2, a redox-sensitive transcription factor, is closely associated with AS pathogenesis [32]. Nrf2\% LDL receptor knockout (LDLR KO) mice exhibited accelerated atherosclerotic lesions as compared with $\mathrm{Nrf}^{+/+}$LDLR KO mice [33]. Increasing studies in vitro have demonstrated that Nrf2 activation is associated with inhibiting oxidative stress as well as inflammation. In endothelial cells, Nrf2 activation is accompanied with decreased ROS generation [34]. Additionally, elevated Nrf2 activity suppresses TNF- $\alpha$-induced MCP-1 secretion, VCAM-1 expression, and NF- $\mathrm{KB}$ pathway [35]. Several natural products, such as curcumin [36], salvianolic acid A [37], and miltirone [38], acting as Nrf2 activators, have been shown to retard AS progression. In the present study, we found that zedoarondiol activated Nrf2 in ox-LDL-treated HUVECs, as evidenced by Nrf2 translocation into the nucleus and upregulation of Nrf2 expression in the nucleus. In addition, the protective effect of zedoarondiol was abolished by ATRA, an Nrf2 inhibitor, suggesting that Nrf2 activation plays a role in the protective effect of zedoarondiol on ox-LDL-induced HUVECs injury.

In physiological conditions, Nrf2 binds to Keap1, locating in the cytoplasm. Oxidative or electrophilic stress enables Nrf2 to release from Keap1 and translocate to the nucleus. 


\section{Cellular Physiology Cell Physiol Biochem 2018;48:1468-1479 \begin{tabular}{l|l} 
DOI: 10.1159/000492257 & $\begin{array}{l}\text { O } 2018 \text { The Author(s). Published by S. Karger AG, Basel } \\
\text { www.karger.com/cpb }\end{array}$
\end{tabular} Mao et al.: Zedoarondiol Attenuates Endothelial Cells Injury via Nrf2}

Thereafter, Nrf2 binds to ARE and induces the transcription of antioxidant and detoxifying genes, among which, HO-1 and NQO1 play crucial roles in anti-atherosclerosis due to their anti-oxidative and anti-inflammatory activities [39, 40]. In this study, zedoarondiol up-regulated expression of HO-1 and NQO1 in injured HUVECs induced by ox-LDL, suggesting that HO-1 and NQO1 are associated with the protective effect of zedoarondiol in oxLDL-induced endothelial cells injury.

In addition, an interesting finding in the present study was that although zedoarondiol showed many favorable effects in ox-LDL-induced endothelial cells injury, it did not have impact on the cells without ox-LDL stimulation, which is meaningful in preventing and treating AS.

Although the present study indicates the protective effect of zedoarondiol on the ox-LDL-induced

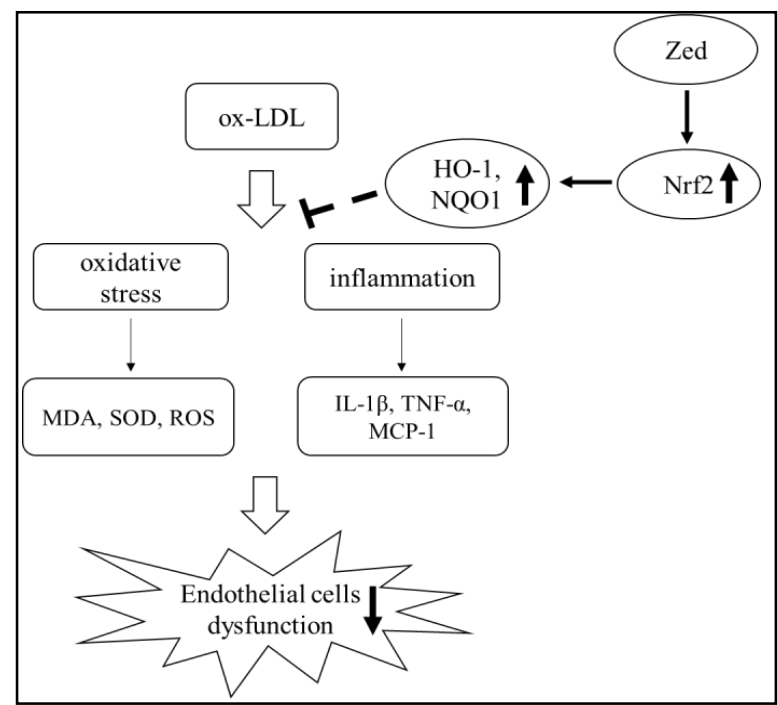

Fig. 6. Proposed mechanism of zedoarondiolmediated protection of ox-LDL-induced HUEVCs injury. Zedoarondiol activates Nrf2 and its downstream target HO-1 and NQ01, resulting in inhibition of inflammation and oxidative stress. All these contribute to zedoarondiolmediated protection of injured endothelial cells. injury of endothelial cells, several limitations should be noted. First, we used ATRA to inhibit Nrf2 activation in the present study, and the results showed that additional ATRA to zedoarondiol pretreatment abolished zedoarondiol-mediated anti-oxidative effect on injured HUVECs. Considering ATRA is an exogenous and non-specific inhibitor of Nrf2, if $\mathrm{Nrf2} \%$ knocked-out cells, or cells genetically knocked down with siRNA were employed in the present studies, whether the cellular protective effect of zedoarondiol is associated with $\mathrm{Nrf} 2$ would be identified more clearly. Second, Nrf2 activation has been evidenced by increased Nrf2 translocation and nuclear Nrf2 expression in the present study. If phosphorylation status of Nrf2 at serine 40 has been examined, the determination of Nrf2 activation would be more credible. Third, intracellular ROS formation was found to be increased with ox-LDL treatment in the present study. However, it did not show the potential sources of intracellular ROS, which needs to be studied in future. Lastly, although the solvent controls were designed in the preliminary experiment and the results showed no significant impact of solvent treatment on HUVECs viability and MDA concentration, the comparison of experimental results between groups would be more reasonable, if the solvent controls were applied in all experiments.

In conclusion, our study demonstrated that zedoarondiol, a sesquiterpene lactone compound extracted from Zedoariae rhizoma, attenuated endothelial cells injury induced by ox-LDL. The underlying mechanism was associated with inhibition of oxidative stress and inflammation via Nrf2 pathway (Fig. 6). These findings suggest that zedoarondiol might be meaningful on prevention and treatment of AS.

\section{Acknowledgements}

This work was supported by the grants from National Science-Technology Support Plan of China (No. 2013BAI02B01), the National Basic Research Program of China (2015CB554402), and the National Natural Science Foundation of China (81473530). 


\section{Cellular Physiology Cell Physiol Biochem 2018;48:1468-1479 \begin{tabular}{l|l} 
and Biochemistry & DOI: 10.1159/000492257 \\
Published onIne: July 2018 The Author(s). Published by S. Karger AG, Basel \\
www.karger.com/cpb
\end{tabular}}

Mao et al.: Zedoarondiol Attenuates Endothelial Cells Injury via Nrf2

\section{Disclosure Statement}

The authors declare no conflicts of interest.

\section{References}

1 Gimbrone MA Jr, García-Cardeña G: Vascular endothelium, hemodynamics, and the pathobiology of atherosclerosis. Cardiovasc Pathol 2013;22:9-15.

-2 Gimbrone MA Jr, García-Cardeña G: Endothelial Cell Dysfunction and the Pathobiology of Atherosclerosis. Circ Res 2016;118:620-636.

3 Salvayre R, Negre-Salvayre A, Camaré C: Oxidative theory of atherosclerosis and antioxidants. Biochimie 2016;125:281-296.

-4 Matsuda H, Ninomiya K, Morikawa T, Yoshikawa M: Inhibitory effect and action mechanism of sesquiterpenes from Zedoariae Rhizoma on D-galactosamine/lipopolysaccharide-induced liver injury. Bioorg Med Chem Lett 1998;8:339-344.

-5 Morikawa T, Matsuda H, Ninomiya K, Yoshikawa M: Potent protective effects of sesquiterpenes and curcumin from Zedoariae Rhizoma on liver injury induced by D-galactosamine/lipopolysaccharide or tumor necrosis factor-alpha. Biol Pharm Bull 2002;25:627-631.

6 Cho W, Nam JW, Kang HJ, Windono T, Seo EK, Lee KT: Zedoarondiol isolated from the rhizoma of Curcuma heyneana is involved in the inhibition of iNOS, COX-2 and pro-inflammatory cytokines via the downregulation of NF-kappaB pathway in LPS-stimulated murine macrophages. Int Immunopharmacol 2009;9:1049-1057.

7 Zhao FH, Liu JG, Wang X, Zhang DW, Wang PL, Zhang L, Du JP, Li XZ, Ma YL, Shi Y, Shi DZ: Long-term effect of stent coating with zedoary essential components on neointimal formation in the porcine coronary artery. Chin J Integr Med 2013;19:771-776.

$>8$ Mao HM, Tao TQ Song DD, Liu M, Wang XR, Liu XH, Shi DZ: Zedoarondiol Inhibits Platelet-Derived Growth Factor-Induced Vascular Smooth Muscle Cells Proliferation via Regulating AMP-Activated Protein Kinase Signaling Pathway. Cell Physiol Biochem 2016;40:1506-1520.

-9 Mitra S, Goyal T, Mehta JL: Oxidized LDL, LOX-1 and atherosclerosis. Cardiovasc Drugs Ther 2011;25:419429.

10 Jiang JX, Zhang SJ, Liu YN, Lin XX, Sun YH, Shen HJ, Yan XF, Xie QM: EETs alleviate ox-LDL-induced inflammation by inhibiting LOX-1 receptor expression in rat pulmonary arterial endothelial cells. Eur J Pharmacol 2014;727:43-51.

11 Cominacini L, Rigoni A, Pasini AF, Garbin U, Davoli A, Campagnola M, Pastorino AM, Lo Cascio V, Sawamura T: The binding of oxidized low density lipoprotein (ox-LDL) to ox-LDL receptor-1 reduces the intracellular concentration of nitric oxide in endothelial cells through an increased production of superoxide. J Biol Chem 2001;276:13750-13755.

12 Niture SK, Khatri R, Jaiswal AK: Regulation of Nrf2-an update. Free Radic Biol Med 2014;66:36-44.

13 Ding Y, Zhang B, Zhou K, Chen M, Wang M, Jia Y, Song Y, Li Y, Wen A: Dietary ellagic acid improves oxidantinduced endothelial dysfunction and atherosclerosis: role of Nrf2 activation. Int J Cardiol 2014;175:508-514.

$\checkmark 14$ Chen XL, Dodd G, Thomas S, Zhang X, Wasserman MA, Rovin BH, Kunsch C: Activation of Nrf2/ARE pathway protects endothelial cells from oxidant injury and inhibits inflammatory gene expression. Am J Physiol Heart Circ Physiol 2006;290:H1862-1870.

15 Jiang S, Yang Y, Li T, Ma Z, Hu W, Deng C, Fan C, Lv J, Sun Y, Yi W: An overview of the mechanisms and novel roles of Nrf2 in cardiovascular diseases. Expert Opin Ther Targets 2016;20:1413-1424.

16 Lu MC, Ji JA, Jiang ZY, You QD: The Keap1-Nrf2-ARE Pathway As a Potential Preventive and Therapeutic Target: An Update. Med Res Rev 2016;36:924-963.

17 Bao MH, Zhang YW, Zhou HH: Paeonol suppresses oxidized low-density lipoprotein induced endothelial cell apoptosis via activation of LOX-1/p38MAPK/NF-kB pathway. J Ethnopharmacology 2013;146:543-551.

18 Ding S, Hou X, Yuan J, Tan X, Chen J, Yang N, Luo Y, Jiang Z, Jin P, Dong Z, Feng L, Jia X: Wedelolactone protects human bronchial epithelial cell injury against cigarette smoke extract-induced oxidant stress and inflammation responses through Nrf2 pathway. Int Immunopharmacol 2015;29:648-655.

19 Mitra S, Goyal T, Mehta JL: Oxidized LDL, LOX-1 and atherosclerosis. Cardiovasc Drugs Ther 2011;25(5):41929. 


\section{Cellular Physiology Cell Physiol Biochem 2018;48:1468-1479

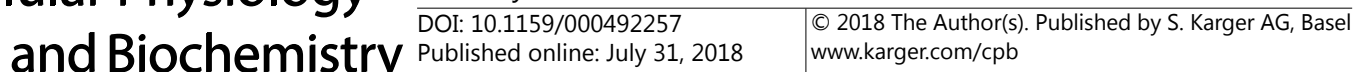

Mao et al.: Zedoarondiol Attenuates Endothelial Cells Injury via Nrf2

-20 Hwang AR, Han JH, Lim JH, Kang YJ, Woo CH: Fluvastatin inhibits AGE-induced cell proliferation and migration via an ERK5-dependent Nrf2 pathway in vascular smooth muscle cells. PLoS One 2017;12:e0178278.

-21 Mylroie H, Dumont O, Bauer A, Thornton CC, Mackey J, Calay D, Hamdulay SS, Choo JR, Boyle JJ, Samarel AM, Randi AM, Evans PC, Mason JC: PKCE-CREB-Nrf2 signalling induces HO-1 in the vascular endothelium and enhances resistance to inflammation and apoptosis. Cardiovasc Res 2015;106:509-519.

-22 Tabas I, García-Cardeña G, Owens GK: Recent insights into the cellular biology of atherosclerosis. J Cell Biol 2015;209:13-22.

-23 Dimmeler S, Haendeler J, Galle J, Zeiher AM: Oxidized low-density lipoprotein induces apoptosis of human endothelial cells by activation of CPP32-like proteases. A mechanistic clue to the 'response to injury' hypothesis. Circulation 1997;95:1760-1763.

-24 Liu Y, Zheng L, Wang Q, Hu YW: Emerging roles and mechanisms of long noncoding RNAs in atherosclerosis. Int J Cardiol 2017;228:570-582.

-25 Kim H, Yun J, Kwon SM: Therapeutic Strategies for Oxidative Stress-Related Cardiovascular Diseases: Removal of Excess Reactive Oxygen Species in Adult Stem Cells. Oxid Med Cell Longev 2016;2016:2483163.

26 Chen XP, Xun KL, Wu Q Zhang TT, Shi JS, Du GH: Oxidized low density lipoprotein receptor-1 mediates oxidized low density lipoprotein-induced apoptosis in human umbilical vein endothelial cells: role of reactive oxygen species. Vascul Pharmacol 2007;47:1-9.

27 Sadat U, Jaffer FA, van Zandvoort MA, Nicholls SJ, Ribatti D, Gillard JH: Inflammation and neovascularization intertwined in atherosclerosis: imaging of structural and molecular imaging targets. Circulation 2014;130:786-794.

28 Onat D, Brillon D, Colombo PC, Schmidt AM: Human vascular endothelial cells: a model system for studying vascular inflammation in diabetes and atherosclerosis. Curr Diab Rep 2011;11:193-202.

-29 Zernecke A, Weber C: Inflammatory mediators in atherosclerotic vascular disease. Basic Res Cardiol 2005;100:93-101.

-30 Yadav A, Saini V, Arora S: MCP-1: chemoattractant with a role beyond immunity: a review. Clin Chim Acta 2010;411:1570-1579.

-31 Khan R, Spagnoli V, Tardif JC, L'Allier PL: Novel anti-inflammatory therapies for the treatment of atherosclerosis. Atherosclerosis 2015;240:497-509.

32 Howden R: Nrf2 and cardiovascular defense. Oxid Med Cell Longev 2013;2013:104308.

-33 Collins AR, Gupte AA, Ji R, Ramirez MR, Minze LJ, Liu JZ, Arredondo M, Ren Y, Deng T, Wang J, Lyon CJ, Hsueh WA: Myeloid deletion of nuclear factor erythroid 2-related factor 2 increases atherosclerosis and liver injury. Arterioscler Thromb Vasc Biol 2012;32:2839-2846.

34 Chen B, Lu Y, Chen Y, Cheng J: The role of Nrf2 in oxidative stress-induced endothelial injuries. J Endocrinol 2015;225:R83-99.

-35 Pae HO, Oh GS, Lee BS, Rim JS, Kim YM, Chung HT: 3-Hydroxyanthranilic acid, one of L-tryptophan metabolites, inhibits monocyte chemoattractant protein-1 secretion and vascular cell adhesion molecule-1 expression via heme oxygenase-1 induction in human umbilical vein endothelial cells. Atherosclerosis 2006;187:274284.

-36 Soltani B, Bodaghabadi N, Mahpour G, Ghaemi N, Sadeghizadeh M: Nanoformulation of curcumin protects HUVEC endothelial cells against ionizing radiation and suppresses their adhesion to monocytes: potential in prevention of radiation-induced atherosclerosis. Biotechnol Lett 2016;38:2081-2088.

-37 Zhang H, Liu YY, Jiang Q, Li KR, Zhao YX, Cao C, Yao J: Salvianolic acid A protects RPE cells against oxidative stress through activation of Nrf2/HO-1 signaling. Free Radic Biol Med 2014;69:219-228.

-38 Zhang L, Zhang H, Li X, Jia B, Yang Y, Zhou P, Li P, Chen J: Miltirone protects human EA.hy926 endothelial cells from oxidized low-density lipoprotein-derived oxidative stress via a heme oxygenase-1 and MAPK/ Nrf2 dependent pathway. Phytomedicine 2016;23:1806-1813.

-39 Van-Assche T, Huygelen V, Crabtree MJ, Antoniades C: Gene therapy targeting inflammation in atherosclerosis. Curr Pharm Des 2011;17:4210-4223.

40 Juan SH, Lee TS, Tseng KW, Liou JY, Shyue SK, Wu KK, Chau LY: Adenovirus-mediated heme oxygenase-1 gene transfer inhibits the development of atherosclerosis in apolipoprotein E-deficient mice. Circulation 2001;104:1519-1525. 